\title{
THE IMPACT OF DIGITAL PHOTOGRAPHY PROCESSING IN MOBILE APPLICATIONS ON THE QUALITY OF REACH IN SOCIAL MEDIA
}

\author{
Magdalena Paśnikowska-Łukaszuk, Arkadiusz Urzędowski \\ Lublin University of Technology, Faculty of Fundamentals, Lublin, Poland
}

Abstract. Modern technologies allow for quick processing of digital images. In the era of the Internet, there are many mobile applications supporting the digital processing of photos used on social media. The algorithms of many popular social networks focus on many factors, however, the photography that is placed on a given portal is of great importance. Social media allows you to reach many sources and people. With the help of a good photo, we can get high post reach that contain additional information. The use of mobile applications helps to achieve very good results. This paper presents the results obtained in the process of comparing posts using digital photo processing with those in which the photos were used without processing in a graphics program.

Keywords: mobile communication, digital communication, social media, multimedia communication

\section{WPLYW CYFROWEGO PRZETWARZANIA FOTOGRAFII W MOBILNYCH APLIKACJACH NA ZWIĘKSZANIE ZASIĘGU W MEDIACH SPOŁECZNOŚCIOWYCH}

Streszczenie. Nowoczesne technologie pozwalaja na szybkie przetwarzanie obrazów cyfrowych. W dobie rozwoju Internetu pojawia się wiele aplikacji mobilnych wspomagajacych proces obróbki cyfrowej zdjęć używanych $w$ mediach społecznościowych. Algorytm wielu popularnych portali spolecznościowych skupia sie na wielu czynnikach, jednakże duże znaczenie ma fotografia, która zostaje umieszczona na danym portalu. Media społecznościowe pozwalają dotrzeć do wielu źródeł i osób. Za pomoca dobrego zdjęcia można uzyskać wysokie zasięgi postów, w których zawarte sa dodatkowe informacje. Wykorzystanie aplikacji mobilnych pomaga uzyskać bardzo dobre efekty. W niniejszej pracy zostana przedstawione wyniki uzyskane $w$ procesie porównywania postów wykorzystujacych obróbke cyfrowa zdjęć oraz tych, $w$ których fotografie były użyte bez przetworzenia w programie graficznym.

Słowa kluczowe: komunikacja mobilna, komunikacja cyfrowa, media społecznościowe, komunikacja multimedialna

\section{Introduction}

Currently, the development of technology is conducive to the appearance of more and more new solutions in the field of computer graphics. The pace of the appearance of smartphones, tablets and other mobile devices on the market has led to more and more people becoming interested in mobile applications. The usefulness of these devices means that on many operating systems, applications which were meant to facilitate everyday functioning and work in many areas of life and science began to develop very quickly [1]. In addition, this development contributed to the popularization of social media, which to a large extent was to serve primarily interpersonal contacts. Over time, they were also used to promote many products, and then these media began to replace traditional websites in favor of profiles on social networks. The most popular of them are Facebook and Instagram [2]. A few years ago, the Internet community also used portals in the form of mobile applications such as Snapchat, which was used to transfer content in the form of photos and videos, but over time, its popularity was replaced by the aforementioned Instagram, which operates on the basis of an algorithm.

Most of the posts that appear on social media are based on a photo and then a description. However, it is the photo that is designed to attract attention and then make the user want to read the rest of the post. Today, more and more programs popping up to adapt their editing tools for social media. Figure 1 present the most popular social media platforms in 2020.
One of these programs is the Canva application, which can be used on both mobile devices and computers. The templates used in this application allow you to prepare appropriate graphics that can be used to post information on social networks. It is worth adding, however, that the most popular applications are those that help to obtain the appropriate reach. Due to the fact that currently every potential recipient is focused on the quick reception of content, the person who prepares this content must be sure that the material prepared by them will get noticed. Therefore, mobile application manufacturers offer a number of tools to facilitate this task.

\section{Popular mobile applications for processing digital images}

The Android system and IOS offer a number of applications supporting the digital processing process. Currently, the most popular are Adobe Lightroom Mobile version and Snapseed. The first mentioned program is popular among computer graphic designers in the traditional version used on computers. Currently, this application has been disseminated by using so-called Presets. These are tool settings that allow you to quickly obtain a digitally processed photo without spending a lot of time, and this effect also allows you to obtain photos which are similar in color. Its modern design and friendly interface allow the user to obtain a satisfactory digital photo processing effect.

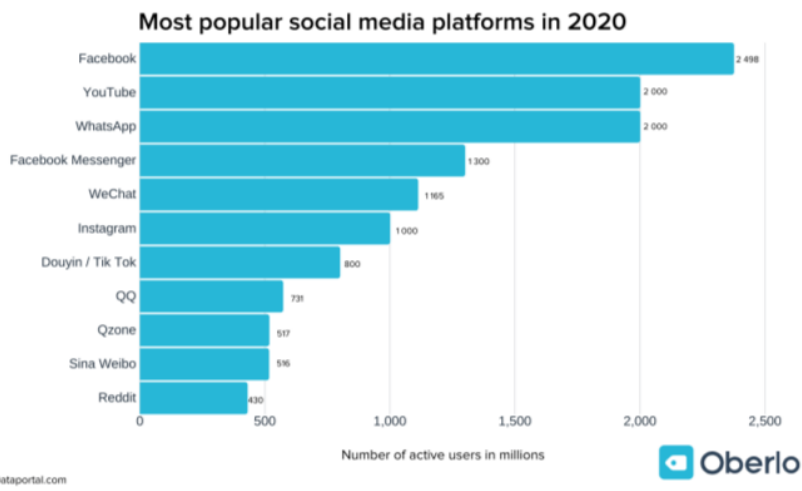


An example of editing a photo in Adobe Lightroom Mobile is shown in Figures 2 and 3. It can be seen that the second photo catches the eye with its unusual colors and reflects a modern effect. In addition, this application allows you to enhance the edges, which is useful when the photo was moved during recording.

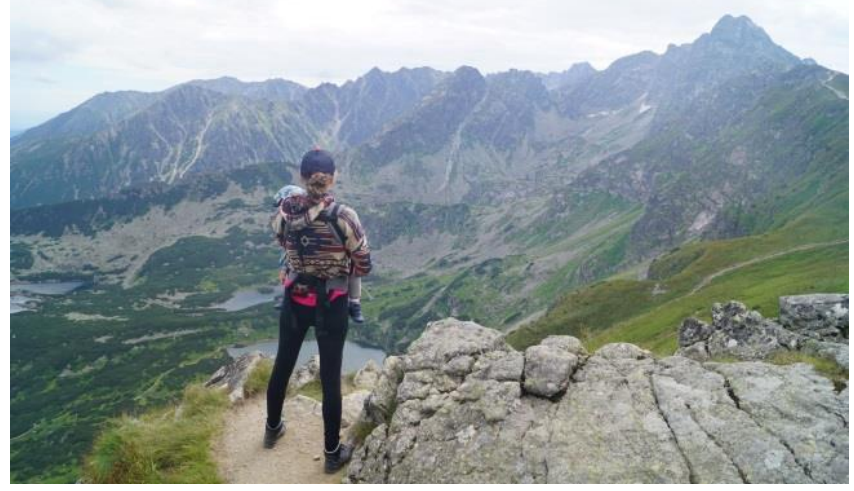

Fig. 2. Photo before digital processing in Adobe Lightroom

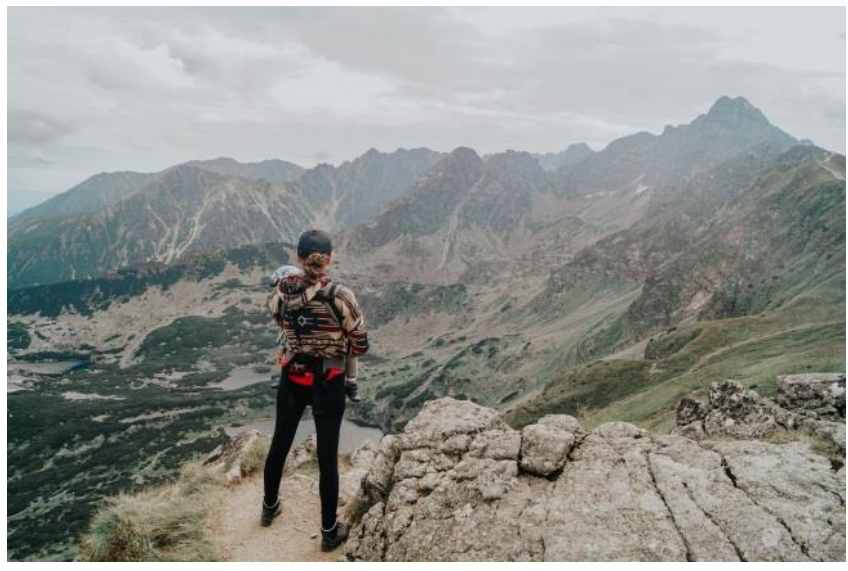

Fig. 3. Photo after digital processing in Adobe Lightroom

The Snapseed mobile application is a combination of many tools that create a fast and very useful program that helps to achieve an effect similar to if you were using Adobe Photoshop. Together with changing the colors and focus settings, the application also offers photo retouching and photomontage tools. In addition, the user can obtain a background blur effect, which can be created by using appropriate photographic equipment, while here, it is enough to use one tool. The application offers a number of filters to facilitate the process of high-speed digital processing. In addition, Snapseed and Adobe Lightroom allow you to share files directly to your social accounts. With the Android overlay, we can also enjoy direct file sending between users. An example of editing a photo in Snapseed is shown in Figures 4 and 5.

There are more and more new applications for digital photo processing in mobile application stores, but practically all of them are based on the same tools as Adobe Lightroom or Snapseed discussed in this chapter. Some are even confusingly similar. However, it is worth choosing one that will help you achieve the right end results.

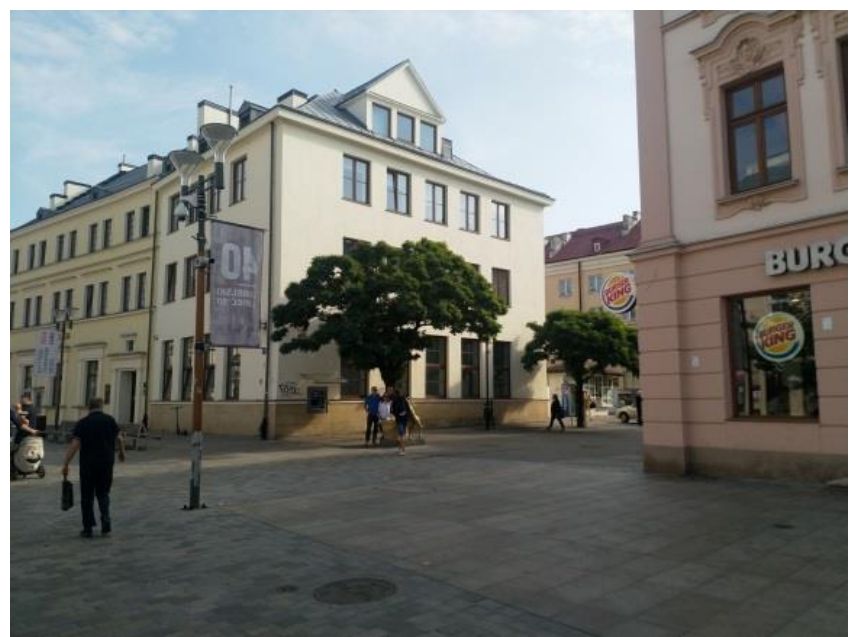

Fig. 4. Photo before digital processing in Snapseed mobile application

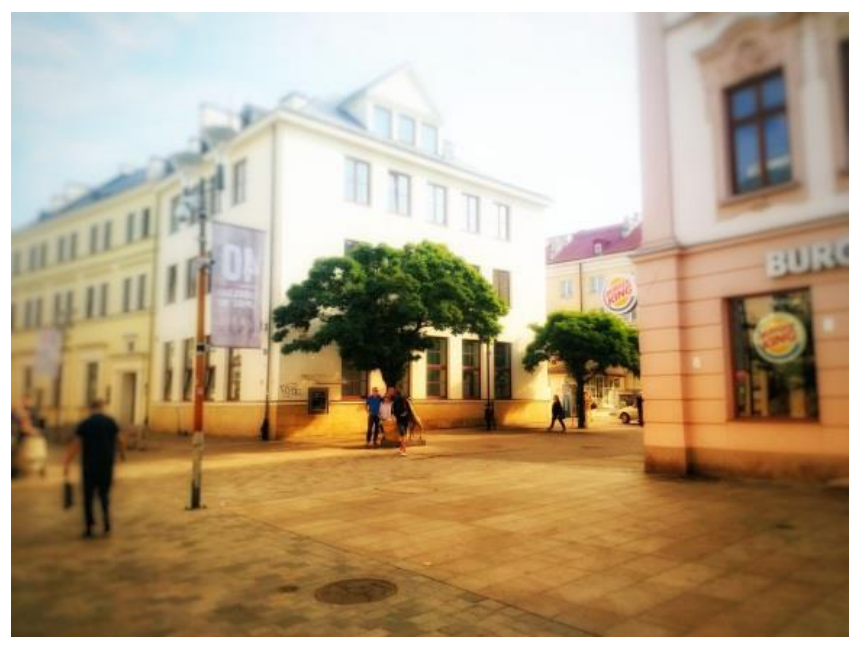

Fig. 5. Photo after digital processing in Snapseed mobile application

\section{Social media in the era of Internet development}

Currently, Facebook is the most popular portal on the market. It is a huge platform that has changed to a business tool from a profile intended for interpersonal contacts. Today, most Facebook users have to deal with other people's advertising and business profiles $[3,5,7]$. We can reach multiple audiences with business settings. The Facebook and Instagram algorithm (which will be discussed later in the article) are based on the user's interests. Non-interest posts tend to have fewer views. The more views of a given post, the greater the reach. Most people ask themselves how to increase the reach of a given post. The basic tool that is supposed to increase the displays is photography. This is the main point that will encourage the users to read the content at a later stage. A good photo equals a good reception. Since Facebook is built as a scrolled page, the mobile version of the application should also be adapted to the format of the page and the application [4, 8]. Therefore, we may notice an increase in views if the image is vertical rather than horizontal, hence the length of the recipient's focus. Vertical photos are meant to "draw" the users' attention. Vertical photos take up more screen real estate on the device. It is similar with the Instagram application. Unlike Facebook, users here focus more on content transmitted primarily in the form of graphics or videos. It should be added that video posts have also been available on Facebook for some time. Figures 6 and 7 show statistics on how many views were generated on pages that used vertical photos and horizontal photos. 


\begin{tabular}{|c|c|}
\hline \multicolumn{2}{|l|}{ Insights } \\
\hline Last 28 days: 29 Au & \\
\hline People reached & $\begin{array}{l}875 \\
-294 \%\end{array}$ \\
\hline $\begin{array}{l}\text { Post } \\
\text { engagements }\end{array}$ & $\begin{array}{r}\mathbf{4 0} \\
-122 \%\end{array}$ \\
\hline Page likes & $\underset{-82 \%}{24}$ \\
\hline
\end{tabular}

Fig. 6. Stats for a page using horizontal photos

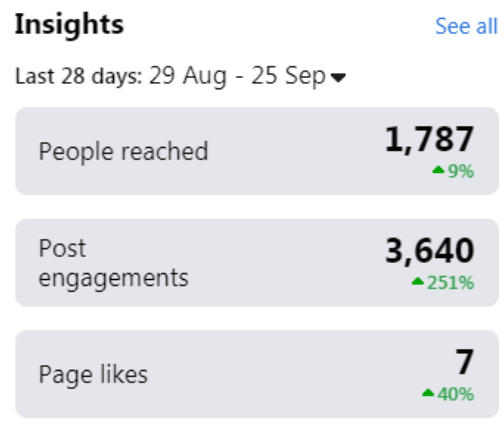

Fig, 7. Stats for a page using vertical photos

We can see an over two-fold increase in the response to published content. Many factors contributed to this result. In order to check the additional effectiveness of photo editing, a study was conducted involving the publication of photos using digital processing in a mobile application. The results will be discussed in the next section. Instagram also generates views by using tools such as hashtags. However, nowadays, filtered photos are an effective way to attract attention. The Instagram application itself offers a number of filters to help achieve the effect of a digitally processed photo. The interface is shown in Figure 8.
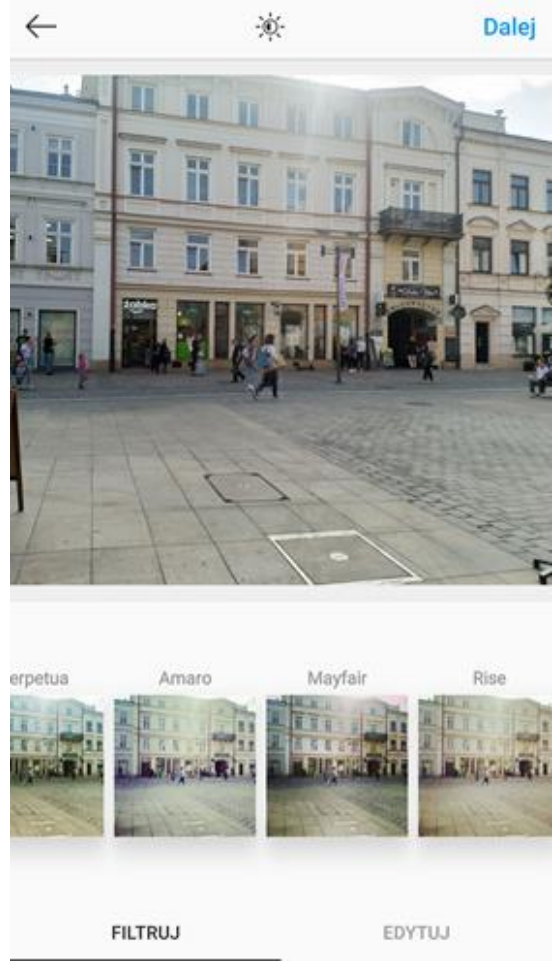

Fig. 8. Interface of Instagram editor
The editor in the Instagram application also allows you to properly crop the photo in order to cover as much vertical real estate as possible. To check the statistics of published photos, the user has to switch a private account to a business account [6]. Then they have a complete preview of how their content is received.

\section{Researching the reach of posts using photography}

In order to obtain the data, several posts on Instagram were published using photography without digital processing and one that was edited with presets in the Adobe Lightroom Mobile application. The ranges resulting from the display of the post were monitored. Figure 9 shows an example of a statistic from a post in which a digitally processed photo was published.

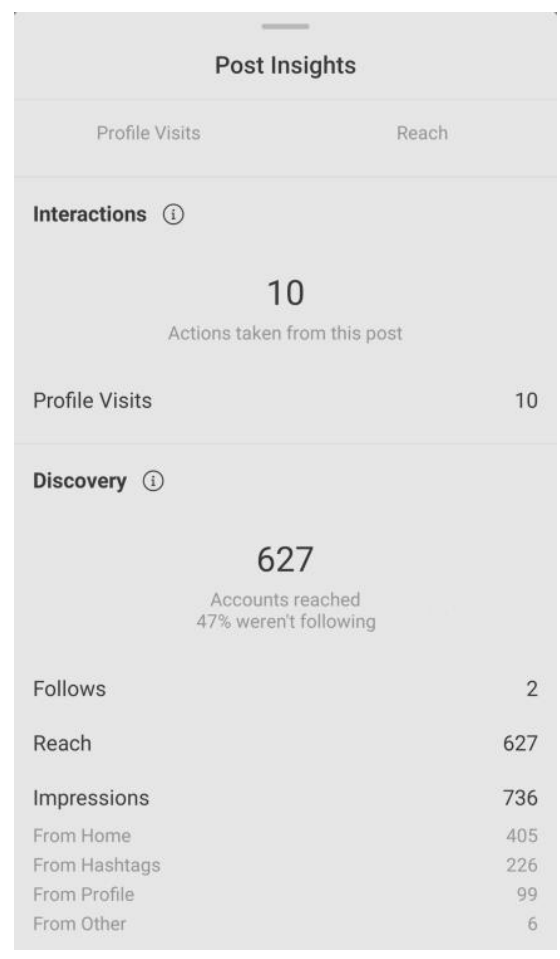

Fig. 9. Instagram statistics

Tables 1-4 show the results of 20 digitally processed posts and 20 posts where the photos were published without processing.

Table 1. Results of published post with photography without post processing

\begin{tabular}{|c|c|c|c|}
\hline Number of post & Follows & Reach & Impressions \\
\hline 1 & 2 & 500 & 861 \\
\hline 2 & 1 & 550 & 932 \\
\hline 3 & 0 & 460 & 785 \\
\hline 4 & 1 & 450 & 461 \\
\hline 5 & 2 & 434 & 788 \\
\hline 6 & 2 & 456 & 772 \\
\hline 7 & 2 & 468 & 755 \\
\hline 8 & 2 & 493 & 774 \\
\hline 9 & 1 & 575 & 685 \\
\hline 10 & 0 & 515 & 604 \\
\hline
\end{tabular}

Table 2. Results of published post with photography without post processing

\begin{tabular}{|c|c|c|c|}
\hline Number of post & Follows & Reach & Impressions \\
\hline 11 & 0 & 572 & 664 \\
\hline 12 & 1 & 692 & 794 \\
\hline 13 & 2 & 575 & 670 \\
\hline 14 & 2 & 612 & 706 \\
\hline 15 & 0 & 645 & 741 \\
\hline 16 & 0 & 669 & 778 \\
\hline 17 & 1 & 611 & 713 \\
\hline 18 & 1 & 599 & 700 \\
\hline 19 & 1 & 502 & 597 \\
\hline 20 & 3 & 440 & 514 \\
\hline
\end{tabular}


Table 3. Results of published post with photography with post processing

\begin{tabular}{|c|c|c|c|}
\hline Number of post & Follows & Reach & Impressions \\
\hline 1 & 2 & 728 & 1201 \\
\hline 2 & 2 & 603 & 1005 \\
\hline 3 & 4 & 535 & 900 \\
\hline 4 & 2 & 488 & 865 \\
\hline 5 & 4 & 539 & 909 \\
\hline 6 & 4 & 504 & 842 \\
\hline 7 & 5 & 512 & 855 \\
\hline 8 & 4 & 609 & 942 \\
\hline 9 & 3 & 683 & 849 \\
\hline 10 & 4 & 689 & 805 \\
\hline \multicolumn{4}{|l}{} \\
\hline
\end{tabular}

Table 4. Results of published post with photography with post processing

\begin{tabular}{|c|c|c|c|}
\hline Number of post & Follows & Reach & Impressions \\
\hline 11 & 4 & 798 & 917 \\
\hline 12 & 2 & 843 & 967 \\
\hline 13 & 4 & 1345 & 1502 \\
\hline 14 & 3 & 770 & 886 \\
\hline 15 & 4 & 996 & 1089 \\
\hline 16 & 4 & 1018 & 1124 \\
\hline 17 & 3 & 1068 & 1197 \\
\hline 18 & 3 & 901 & 993 \\
\hline 19 & 3 & 829 & 967 \\
\hline 20 & 5 & 1054 & 1102 \\
\hline \multicolumn{3}{|l}{} \\
\hline
\end{tabular}

The comparison of the results is presented in the diagram (Figure 10). You can see a significant increase in interaction in the case of publishing photos that were processed in the Adobe Lightroom application. The modern design of the photography caught the attention of followers as well as new users. The trend line is upward. The same hashtags were used in the posts to exclude the influence of other factors. However, it should be added here that properly selected hashtags also boost views, but they must be matched to the content and the photo that is published. In addition to impressions and increased range, we should see an increase in new followers. These are small numbers, but still representing an upward trend. Summing up, using presets in Adobe Lightroom has a positive effect on the increase in statistical factors in the Instagram application when publishing content.

\section{Conclusions}

Digital processing has a huge impact on the viewing of posts by users. At the same time, it contributes to the growth of observers on social media. Photos with bright colors in warm tones had more views than photos with sharp colors. Posts with photos processed in the mobile application had more comments and reactions from observers. In addition, the posts encouraged users to read the rest of the content. It can therefore be concluded that the processing of digital images is conducive to building ranges and relationships between users, and the use of additional tools such as hashtags or marking locations strengthens these ranges. Through the desire to gain coverage in social media, users also develop their skills in using graphics programs, and this also increases market demand for the production of mobile applications for digital photo processing. Manufacturers can also reach a new audience in this way. To sum up, if the user wants to achieve very good results in the form of an increase in reach and display of published content, they should use an image and photography processing application.

\section{References}

[1] Bevilaqua M.: Guide to image editing and production of figures for scientific publications with an emphasis on taxonomy. Zoosystematics and Evolution 96(1), 2020, 139-158.

[2] Davies T., Lorne C., Salley-Huggins L.: Instagram photography and the geography field course: snapshots from Berlin. Journal of Geography in Higher Education 43(3), 2019, 362-383 [http://doi.org/ 10.1080/03098265.2019.1608428]

[3] Hemesley J., Jacobson J., Gruzd A., Mai P.: Social Media for Social Good or Evil: An Introduction. Sage Journals 4(3), 2018 [http://doi.org/10.1177/2056305118786719].

[4] Hochman N.: The social media image. Sage Journals 1(2), 2014 [http://doi.org/10.1177/2053951714546645].

[5] Korga S., Płecha A., Szulżyk-Cieplak A.: Media społecznościowe w dobie społeczeństwa informatycznego. Poszerzamy horyzonty 5, 2017, 158-166.

[6] Perrin A.: Social Media Usage: 2005-2015. Pew Research Center, October, 2015.

[7] Skowron S., Skrzetuski R.: Media społecznościowe jako narzędzie komunikacji firmy z klientem. Handel Wewnętrzny 359(6), 2015, 162-172.

[8] Szulżyk-Cieplak J., Puchtel A., Płecha A.: Media społecznościowe jako narzędzia reklamy internetowej. Edukacja - Technika - Informatyka 20(2), 2017, 290-295.

[9] https://www.oberlo.com/statistics/most-popular-social-media-platforms (accessed: 26.09.2020)

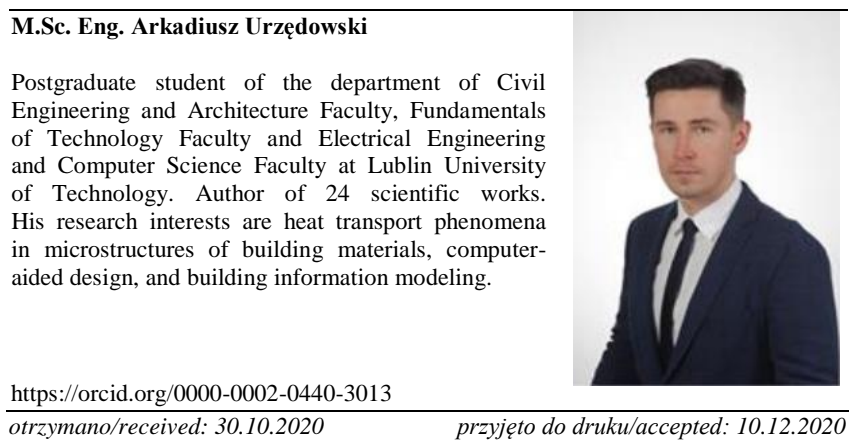

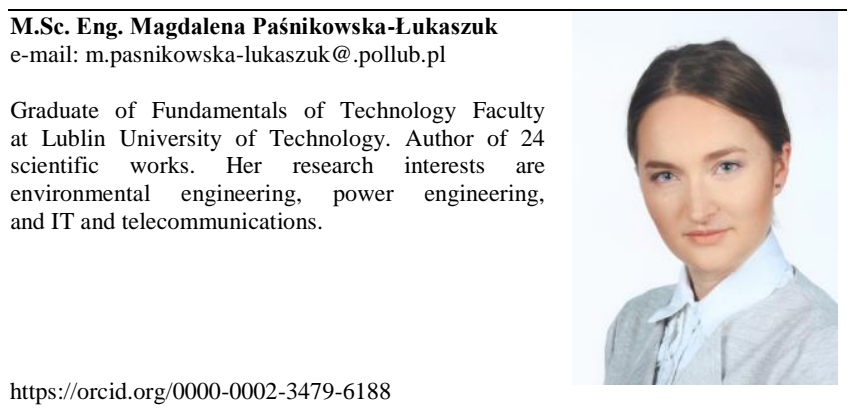

M.Sc. Eng. Magdalena Paśnikowska-Łukaszuk

Graduate of Fundamentals of Technology Faculty at Lublin University of Technology. Author of 24 environmental engineering, power engineering. 